\title{
Pengembangan Media Buku Pop-Up untuk Meningkatkan Kemampuan Menyimak Tema Menyayangi Tumbuhan dan Hewan di Sekitar
}

\author{
Qori Kartika Putri ${ }^{1}$, Pratjojo ${ }^{2}$, Arfilia Wijayanti ${ }^{3}$ \\ ${ }^{1,2,3}$ PGSD Universitas PGRI Semarang, JI Sidodadi Timur No 24 Semarang \\ e-mail: qorikartikaputri95@gmail.com
}

\begin{abstract}
Abstrak
Penggunaan media pembelajaran dirancang untuk mengembangkan cara belajar siswa agar lebih menarik sehingga dibuatlah suatu alat peraga seperti media buku pop up. Media buku pop up adalah media kertas yang apabila dibuka akan muncul obyek yang berbentuk tiga dimensi. Pengembangan media buku pop up menghasilkan media buku pop up yang dapat diterapkan pada tema menyayangi tumbuhan dan hewan disekitar untuk kelas III SD Pedurungan Kidul 04 Semarang. Tujuan dalam pengembangan ini adalah untuk mengembangkan media buku pop up pada tema menyayangi tumbuhan dan hewan di sekitar sehingga meningkatkan kemampuan menyimak siswa dilihat dari hasil validasi ahli yang menyatakan layak dan hasil pretest posttest yang menunjukan peningkatan. Adapun manfaat yang didapat dari adanya media buku pop up tersebut ialah dapat memberikan wawasan dan pengetahuan kepada siswa serta bahan referensi bagi pembaca atau peneliti berikutnya terkait dengan pengembangan buku pop up untuk menumbuhkan kemampuan menyimak. Dari pengujian validasi yang dilakukan oleh ahli media pembelajaran dengan rata-rata persetase $90.00 \%$ dalam kategori baik sekali, dari penguji validasi yang dilakukan oleh ahli materi pembelajaran dengan rata-rata persentase sebanyak $95.99 \%$ dalam kategori baik sekali, dan dari hasil evaluasi 25 siswa memperoleh nilai rata-rata pretest 68.22 dan nilai rata-rata posttest 86.36, N gain menunjukan 0.57 dalam kategori sedang. Sehingga dapat dikatakan bahwa media buku pop up sesuai dan layak digunakan.
\end{abstract}

Kata Kunci: pengembangan, media buku pop up, kemampuan menyimak

\begin{abstract}
The application of instructional media is designed to develop a student's way of learning so that becomes more interesting till is made a prop such as pop up books. Pop up books are paper media which when opened will pop the objects in three dimensional shape. The development of pop up books results in the pop-up books which could be applied for the theme of loving plants and animals around for third grade in Pedurungan Kidul 04 state elementary Semarang. The purpose of this development of pop up books results in the which could be applied for the theme of loving plants and animals. The benefits gained by the availability of pop up books are giving insight and knowledge to the students and reference material for the next reader or researcher related to the development of pop up books to upgrade heeding ability. From validation testing that done by learning media expert with average percentage of $90 \%$ in excellent category, validation testing that done by learning material expert with average percentage of $95.99 \%$ in excellent category, and from evaluation result of 25 students get pretest average score of 68.22 and post-test average score of $86.36, \mathrm{~N}$ gain shows 0.57 in the average category. Therefore it could be said that pop up books media is convenient and proper to be used.
\end{abstract}

Keywords: Development, media pop up book, heeding ability 


\section{Pendahuluan}

Pendidikan merupakan suatu proses yang mencakup tiga dimensi, individu, masyarakat atau komunitas nasional dari individu tersebut, dan seluruh kandungan realitas, baik material maupun spiritual yang memainkan peranan dalam menentukan sifat, nasib, bentuk manusia maupun masyarakat. Pendidikan lebih dari sekedar pengajaran, yang dapat dikatakan sebagai suatu proses transfer ilmu, transformasi nilai, dan pembentukan kepribadian dengan segala aspek yang dicakupnya. Dengan demikian pengajaran lebih berorientasi pada pembentukan spesialis atau bidang-bidang tertentu, oleh karena itu perhatian dan minatnya lebih bersifat teknis (Nurkholis ,2013).

Undang-Undang Republik Indonesia No. 20 tahun 2003 tentang Sistem Pendidikan Nasional, pendidikan adalah usaha sadar dan terencana untuk mewujudkan suasana belajar dan pembelajaran agar peserta didik mengembangkan potensi dirinya untuk memiliki kekuatan spiritual keagamaan, pengendalian diri, kepribadian, kecerdasan, akhlak mulia, serta keterampilan yang diperlukan dirinya, masyarakat, bangsa, dan negara. Pendidikan Nasional adalah pendidikan yang didasarkan pancasila dan Undang-Undang Dasar Republik Indonesia tahun 1945 yang berakar pada nilai-nilai agama, kebudayaan nasional Indonesia dan tanggap terhadap kemajuan zaman.Tujuan pendidikan nasional yang dirumuskan dalam UU SISDIKNAS adalah untuk mengembangkan potensi anak didik agar menjadi manusia yang beriman dan bertakwa kepada Tuhan Yang Maha Esa, berakhlak mulia, sehat, berilmu, cakap, kreatif, mandiri, dan menjadi warga Negara yang demokratis serta bertanggung jawab (Munirah ,2015).

Sugiyono (2017:407) metode penelitian dan pengembangan yang dalam bahas inggris disebut dengan Research and Development adalah metode penelitian yang digunakan untuk menghasilkan produk tertentu dan menguji keefektifan produk tersebut. Sehingga pengembangan merupakan pembaharuan dari apa yang telah dibuat oleh para pakar atau membuat karya baru yang dapat menunjang suatu perubahan yang lebih baik.

Kata "media" berasal dari bahasa Latin "medium" yang berarti "perantara" atau "pengantar". Lebih lanjut, media merupakan sarana penyalur pesan atau informasi belajar yang hendak disampaikan oleh sumber pesan kepada sasaran atau penerima pesan tersebut. Penggunaan media pengajaran dapat membantu pencapaian keberhasilan belajar. Ditegaskan oleh Danim bahwa hasil penelitian telah banyak membuktikan efektivitas penggunaan alat bantu atau media dalam proses belajar-mengajar di kelas, terutama dalam hal peningkatan prestasi siswa. Terbatasnya media yang dipergunakan dalam kelas diduga merupakan salah satu penyebab lemahnya mutu belajar siswa.1 Dengan demikian penggunaan media dalam pengajaran di kelas merupakan sebuah kebutuhan yang tidak dapat diabaikan. Hal ini dapat dipahami mengingat proses belajar yang dialami siswa tertumpu pada berbagai kegiatan menambah ilmu dan wawasan untuk bekal hidup di masa sekarang dan masa akan datang. Salah satu upaya yang harus ditempuh adalah bagaimana menciptakan situasi belajar yang memungkinkan terjadinya proses pengalaman belajar pada diri siswa dengan menggerakkan segala sumber belajar dan cara belajar yang efektif dan efisien.2 Dalam hal ini, media pengajaran merupakan salah satu pendukung yang efektif dalam membantu terjadinya proses belajar. Wilbur Schram (1982) berpendapat bahwa media adalah Information carying technologies that can be used for instruction The media instruction, consequently are extensions of the teacher. Menurutnya media adalah teknologi pembawa pesan yang dapat dimanfaatkan untuk keperluan pembelajaran. Jadi media adalah perluasan dari guru.7 Pengertian yang dikemukakannya tidak jauh beda dengan pengertian yang dikemukakan oleh Asociation of Education Comunication Technology (AECT), yang mana media diartikan dengan segala bentuk dan saluran yang dapat dipergunakan untuk proses penyalur pesan.8 Dari kedua pendapat tersebut dapat dipahami bahwa media adalah berkaitan dengan perantara yang berfungsi menyalurkan pesan dan informasi dari sumber yang akan diterima oleh si penerima pesan yang terjadi dalam proses pembelajaran (Mahnun ,2012).

Pop up adalah jenis buku atau kartu yang didalamnya terdapat lipatan atau potongan gambar yang muncul sehingga membentuk obyek tiga dimensi (3D). Menurut Ellend G Kreiger Rubin seorang ahli di bidang paper angineering (dalam Fatchul, 2014:146-153) menjelaskan bahwa pop-up adalah sebuah ilustrasi yang ketika halaman tersebut dibuka, ditarik, atau diangkat akan timbul tingkatan dengan kesan tiga dimensi. Dalam pengembangannya peran media sangatlah penting untuk menunjang terbentuknya kreatifitas siswa dalam mengeksplor pembelajaran, seperti media buku pop up ini dapat membantu siswa dalam mempermudah menyelesaikan masalah. media buku pop up yaitu media 3 dimensi yang memberikan suatu 
gambaran nyata untuk mempermudah siswa dalam meningkatkan konsentrasi dalam menyimak.

Media belajar pop-up book dianggap mempunyai daya tarik tersendiri bagi peserta didik karena mampu menyajikan visualisasi dengan bentuk-bentuk yang dibuat dengan melipat, bergerak dan muncul sehingga memberikan kejutan dan kekaguman bagi peserta didik ketika membuka setiap halamannya (Khoiraton dkk., 2014). Kelebihan dari media pop-up book adalah memberikan pengalaman khusus pada peserta didik karena melibatkan peserta didik seperti menggeser, membuka, dan melipat bagian pop-up book. Hal ini akan membuat kesan tersendiri kepada pembaca sehingga akan lebih mudah masuk ke dalam ingatan ketika menggunakan media ini (Setyawan dkk., 2014) (Adelilia ,2017).

Media Pop up book dalam bahasa Inggris mempunyai arti muncul keluar. Ann (2018) mengatakan pop up book ialah sebuah media yang berbentukibukuidan memiliki unsuritigaidimensi. Dzuanda (2011: 1) menyatakan pop up book ialah sebuahibuku yang dapat berdiri tegak dan terdiri dari beberapa bagian yang ada di dalamnya yang apabila dirangkai dapat menimbulkan sebuah cerita yang lebih menarik (Nur ,2018).

Russel dan Russell (dalam Guntur, 2008:30) melihat untuk mendengar maka mengamati untuk mendengar dan membaca untuk menyimak. dengan demikian menyimak bermakna mendengarkan dengan penuh pemahaman dan perhatian serta apresiasi.

Penelitian ini didasarkan pada masalah yang berhubungan dengan rendahnya konsentrasi siswa dalam menyimak sehingga hasil belajar kurang. Oleh sebab itu Peneliti menambahkan media buku pop up untuk dapat meningkatkan kemampuan menyimak siswa dengan memberikan prestest dan posttest.

Masalah tersebut dapat diatasi dengan penggunaan media yang tepat dalam pembelajaran. Media yang dirasa tepat untuk mengatasi masalah diatas adalah media buku pop up. Buku pop up ini memudahkan guru memancing siswa untuk berkonsentrasi dalam menyimak dengan berbantu gambar yang muncul dan berbentuk tiga dimensi (3D). Sehingga dengan menggunakan media ini dapat meningkatkan partisipasi siswa untuk berkonsentrasi serta memahami apa yang guru sampaikan dalam proses pembelajaran. Sehingga penelitian ini akan dibuat pengembangan media buku pop up untuk meningkatkan kemampuan menyimak tema menyayangi tumbuhan dan hewan di sekitar, hasil dari cerita yang akan disampaikan ditulis oleh peneliti sendiri.

Menurut (Diah ,2018) yang melakukan penelitian di SD Mutiara mengatakan bahwa Media pembelajaran Pop-Up Book dinyatakan valid dan dapat digunakan untuk peserta didik dalam kegiatan belajar untuk meningkatkan hasil belajar IPA siswa kelas III A SD Mutiara Singaraja. Hal tersebut terbukti dengan hasil dari uji ahli dan uji coba siswa berikut, pada ahli isi mata pelajaran IPA endapatkan hasil 95,8\% dengan kriteria sangat baik, penilaian pada ahli desain pembelajaran mendapatkan hasil $88 \%$ dengan kriteria baik, penilaian ahli media pembelajaran mendapatkan hasil $98,5 \%$ dengan kriteria sangat baik, pada uji coba perorangan mendapatkan hasil $92 \%$ dengan kriteria sangat baik, pada uji coba kelompok kecil mendapatkan hasil $91,66 \%$ dengan kriteria sangat baik, dan pada uji coba lapangan mendapatkan hasil 90,8\% dengan kriteria sangat baik.

Menurut (Dewanti ,2018) Terlihat juga pada hasil uji coba siswa diperoleh skor keseluruhan 152 dengan persentase sebesar 95\%, sehingga termasuk dalam kriteria "Sangat Valid". Hasil pre test dan post test siswa menunjukkan adanya perbedaan nilai rata-rata sebelum penggunaan media dan sesudah penggunaan media, yakni 55,625 dan 82,5. Berdasarkan hasil uji coba siswa pada pre test dan post test untuk kualitas hasil akhir diperoleh kenaikan rata-rata $26,875 \%$ yang berarti media efektif untuk siswa, karena memberikan dampak untuk capaian hasil belajar siswa. Jika menggunakan acuan KKM 70, jumlah siswa yang tidak tuntas pada pre test sebanyak 13 , sedangkan pada post test tidak ada siswa yang tidak tuntas. Hal ini menunjukkan bahwa media Pop-Up Book dapat membantu siswa dalam memahami materi Tempat Tinggalku.

Menurut (Laila ,2017) Hasil uji coba terbatas pengembangan media Pop Up Book berdasarkan respon siswa adalah positif, dengan total persentase rata-rata sebesar $87,5 \%$. Begitupun dengan hasil uji coba kelompok besar berdasarkan respon siswa adalah positif, dengan total persentase rata-rata sebesar $96,9 \%$. Sehingga dapat disimpulkan bahwa siswa sangat tertarik menggunakan media pembelajaran Pop Up Book dan Hasil angket respon guru pada uji coba terbatas diperoleh hasil bahwa persentase setiap indikator lebih dari $65 \%$, dan hanya ada satu indikator yang persentasenya di bawah $65 \%$. Setelah dilakukan revisi dan diuji cobakan pada kelompok besar, diperoleh hasil bahwa persentase setiap indikator lebih dari 65 $\%$. Sehingga dapat dikatakan media Pop Up Book positif terhadap pembelajaran. 
Hal ini di dukung juga oleh Khoiriyah (2018) yang menyatakan bahwa tingkat kelayakan produk oleh ahli materi dan ahli media termasuk dalam kategori valid dan layak digunakan namun perlu direvisi. Dari hasil data keterterapan media menunjukkan hasil media pembelajaran Pop-Up Book valid dan layak diterapkan pada pembelajaran.

Berdasarkan hasil penelitian dan pengembangan yang telah dilakukan Safri (2017), maka disimpulkan bahwa media belajar pop-up book yang telah dikembangkan melalui model ADDIE, melalui tahapan analisis, desain, pengembangan, implementasi dan evaluasi dengan persentase kelayakan rata-rata dari 5 validator sebesar 92,67. Hal ini menunjukan bahwa media belajar pop-up book materi minyak bumi sangat layak digunakan sebagai media pembelajaran.

Kondisi tersebut mendorong peneliti untuk melakukan penelitian dengan judul "Pengembangan Media Buku Pop Up Untuk Meningkatkan Kemampuan Menyimak Tema Menyayangi Tumbuhan dan Hewan di Sekitar Kelas III SD Negeri Pedurungan Kidul 04 Semarang".

\section{Metode}

Jenis penelitian yang akan digunakan peneliti adalah penelitian dan pengembangan (Research and Development). Penelitian ini di pilih karena peneliti mengembangkan produk berupa media pembelajaran. Peneliti dan pengembangan akan menghasilkan produk berupa media buku pop up yang isi ceritanya dibuat dengan hasil karya penulis sendiri pada mata pelajaran Bahasa Indonesia, kemudian dijadikan alternatif yang tentunya akan melalui tahap pengujian terlebih dahulu.

Uji ketuntasan klasikal yang ditemukan oleh peneliti adalah 80\% dari 25 siswa. Setelah dilakukan pretest dan posttest maka suatu kelas dikatakan tuntas jika dalam kelas tersebut terdapat $\geq_{80 \%}$. Sehingga pada kelas III SD Pedurungan Kidul 04 tuntas secara klasikal.

Untuk melihat peningkatan hasil belajar pesertas didik sebelum dan sesudah mendapatkan pembelajaran menggunakan media buku pop up Mutiara dan Rubah, maka dilakukan perhitungan skor gain. Richard Hake (dalam Shodikin, 2012) membuat formula untuk menjelaskan gain secara proposional, yang disebut sebagai normalized gain (gain ternormalisasi). Gain ternormalisasi (g) adalah proporsi antara gain aktual (postes-pretes) dengan gain maksimal (skor ideal - pretest) yang dapat dicapai.

Kualifikasi peningkatan skor gain ternormalisasi tersebut akan dapat dianalisis secara kualitatif kategori / kualitas peningkatan hasil belajar peserta didik sebelum dan sesudah penggunaan media buku pop up.

\section{Hasil dan Pembahasan}

Berdasarkan validasi ahli media hingga ahli materi pembelajaran sehingga dapat di gunakan untuk prosedur penelitian memiliki hasil sebagai berikut:

Perhitungan persetase keidealan tiap aspek oleh ahli media validasi kedua, diperoleh hasil seagai berikut : aspek $1=95.00 \%$ (Baik Sekali), aspek $2=86.66 \%$ (Baik Sekali), aspek $3=$ $85.00 \%$ (Baik Sekali), aspek $4=90.00 \%$ (Baik Sekali), aspek $5=85.00 \%$ (Baik Sekali). Hasil perhitungan validasi pertama dan kedua media buku pop up sudah sangat layak digunakan untuk pembelajaran, semua data dari hasil review, penilaian, dan diskusi dengan ahli media pembelajaran dijadikan bahan pertimbangan penyempurnaan komponen media buku pop up sebelum dilakukan uji coba kepada siswa.

Tabel 1. Hasil Uji Validasi Media Pembelajaran

\begin{tabular}{ccc}
\hline Aspek penilian & \% keidealan & Kategori \\
\hline Indikator kesesuaian & $95.00 \%$ & Baik sekali \\
Kelayakan produk & $86.66 \%$ & Baik sekali \\
Kontribusi produk & $85.00 \%$ & Baik sekali \\
Keunggulan produk & $90.00 \%$ & Baik sekali \\
Kualitas produk & $85.00 \%$ & Baik sekali \\
\hline
\end{tabular}

Hasil perhitungan persentase keidealan tiap aspek oleh ahli materi validasi kedua, diperoleh aspek $1=100.00 \%$ (Baik Sekali), aspek $2=90.00 \%$ (Baik Sekali), aspek $3=100.00 \%$ (Baik Sekali), aspek $4=96.66 \%$ (Baik Sekali). 
Berdasarkan hasil validasi yang telah dijelaskan dapat disimpulkan bahwa menurut penilaian ahli materi dan ahli media semua indikator sudah baik sekali karena materi yang disaji efektif, dapat menambah pemahaman konsep siswa, dapat membangun pemahaman konsep siswa, dan dapat mengembangkan imajinasi dan kreatifitas siswa.

Tabel 2. Hasil Uji Validasi Materi Pembelajaran

\begin{tabular}{ccc}
\hline Aspek penilaian & $\%$ keidealan & Kategori \\
\hline Indikator kesesuaian & $100.00 \%$ & Baik sekali \\
Kelayakan produk & $90.00 \%$ & Baik sekali \\
Indikator penyajian & $100.00 \%$ & Baik sekali \\
Indikator kompetensi & $96.66 \%$ & Baik sekali \\
\hline
\end{tabular}

Setelah melalui tahap uji validasi media dan materi, produk telah dinyatakan valid, maka dapat dilanjutkan ke tahap uji lapangan / implementasi. Siswa diberikan pretest dan posttest untuk mengukur nilai dengan menggunakan $\mathrm{N}$ gain yang telah dijelaskan pada bab sebelumnya. Dengan N gain sedang maka media buku pop up dapat dikatakan layak untuk digunakan. Dapat dilihat bahwa seluruh siswa memahami materi yang diajarkan oleh guru dengan menggunakan media buku pop up. Hal ini dapat diketahui dari tabel dibawah ini

Tabel 3. Data Nilai Siswa

\begin{tabular}{cccc}
\hline Nilai Pretest & Nilai Posttest & N Gain & Kriteria N Gain \\
\hline 68.22 & 86.36 & 0.57 & Sedang \\
\hline
\end{tabular}

Untuk hasil N Gain siswa disajikan tabel hasil frekuensi siswa kelas III SD Pedurungan Kidul 04 pada tabel 4.11 sebagai berikut:

Tabel 4. Data N gain

\begin{tabular}{|c|c|c|c|}
\hline Inter-val Gain & Kriteria & Frekuen-si & Persen-tase (\%) \\
\hline \multirow{4}{*}{$\begin{array}{c}0.7<g \\
0.3<g \leq 0.7 \\
g \leq 0.3\end{array}$} & Tinggi & 8 & $32 \%$ \\
\hline & Sedang & 16 & $64 \%$ \\
\hline & Rendah & 1 & $4 \%$ \\
\hline & Jumlah & 25 & 100 \\
\hline
\end{tabular}

Berdasarkan data hasil evaluasi gain yang diperoleh dapat dikatakan bahwa siswa yang mendapatkan kriteria $0.7<\mathrm{g}$ (tinggi) ada 8 siswa, $0.3<\mathrm{g} \leq 0.7$ (sedang) ada 16 siswa dan yag medapatkan g $\leq 0.3$ (rendah) ada 1 siswa. Hal itu menunjukan bahwa media telah valid atau layak digunakan dalam pembelajaran dan dapat menimbulkan antusiasme belajar siswa serta konsetrasi siswa dan dapat meningkatkan kemampuan menyimak pada pembelajaran sehingga tujuan pembelajaran dapat tercapai. Dengan rata-rata tersebut dapat dilihat bahwa penggunaan media buku pop up layak untuk siswa kelas III SD dan media buku pop up dapat digunakan sebagai media pembelajaran dan hasil pretest dan posttest menunjukan peningkatan.

\section{Simpulan dan Saran}

Berdasarkan rumusan masalah, pengajuan hipotesis, analisis data penelitian dan pembahasan, maka penelitian membuat kesimpulan sebagai berikut: 1) Nilai rata-rata pretest 68.22 dan nilai rata-rata posttest $86.36, \mathrm{~N}$ gain menunjukan 0.57 dalam kategori sedang, dan 2) Dari pengujian validasi yang dilakukan oleh ahli media pembelajaran dengan rata-rata persetase $90.00 \%$ dalam kategori baik sekali, dari penguji validasi yang dilakukan oleh ahli materi pembelajaran dengan rata-rata persentase sebanyak $95.99 \%$ dalam kategori baik sekali. Jadi dapat ditarik kesimpulan bahwa media buku pop up sudah sesuai dan layak digunakan untuk kegiatan pembelajaran 


\section{Daftar Pustaka}

Adelila ,Sri (2017). Pengembangan Media Belajar Pop-Up Book Pada Materi Minyak Bumi . Jurnal Pendidikan Sains Indonesia, Vol. 05, No.01, hlm 107-113, 2017 http://jurnal.unsyiah.ac.id/jpsi

Dewanti ,Handaruni (2018). Pengembangan Media Pop-Up Book Untuk Pembelajaran Lingkungan Tempat Tinggalku Kelas Iv Sdn 1 Pakunden Kabupaten Ponorogo . Jurnal JKTP Volume 1, Nomor 3, September 2018

Elisa Diah. (2018). Pengembangan Media Pembelajaran Pop-Up Book pada Mata Pelajaran IPA Kelas III Sekolah Dasar. Jurnal Jurusan Teknologi Pendidikan.

Fatchul, Muhammad Mubarok Febrianto. 2014. Penerapan Media Dalam Bentuk Pop Up Book Pada Pembelajaran Unsur-Unsur Rupa Untuk Siswa Kelas 2 SDNU Kanjeng Sepuh Sidayu Gresik.

Guntur, Henry Tarigan. 2008. Menyimak Sebagai Suatu Keterampilan Berbahasa. Bandung: Angkasa Bandung.

Hanifah, Tisna Umi. 2014. Pemanfaatan Media Pop-Up Book Berbasis Tematik Untuk Meningkatkan Kecerdasan Verbal-Linguistik Anak Usia 4-5 Tahun (Studi Eksperimen Di Tk Negeri Pembina Bulu Temanggung). EARLY CHILDHOOD EDUCATION PAPERS ( BELIA) 3 (2) http://journal.unnes.ac.id/sju/index.php/belia

Khoiriyah Evi. 2018. Pengembangan Media Pembelajaran Pop-Up Book pada Mata Pelajaran IPA Kelas III SDN 3 Junjung Kecamatan Sumbergempol Kabupaten Tulungagung Tahun Ajaran 2017/2018. Jurnal Bidang Pendidikan Dasar (JBPD), Vol.2 No.2 Juni 2018. http: ejournal.unikama.ac.id/index.php/JBPD

Laila ,Alfi (2017). Pengembangan Media Pop Up Book Untuk Meningkatkan Kemampuan Menulis Kreatif Pada Mata Pelajaran Bahasa Indonesia Materi Menulis Karangan Kelas V Sdn Rowoharjo Tahun Ajaran 2016/2017 . Jurnal Simki-Pedagogia Vol. 01 No. 08 Tahun 2017 ISSN : AAAA-AAAA

Mahnun ,Nunu (2012). Media Pembelajaran (Kajian Terhadap Langkah-Langkah Pemilihan Media Dan Implementasinya Dalam Pembelajaran) . Jurnal Pemikiran Islam; Vol. 37, No. 1 Januari-Juni 2012

Munirah (2015). Sistem Pendidikan Di Indonesia: Antara Keinginan Dan Realita . Jurnal Auladuna, Vol. 2 No. 2 Desember 2015: 233-245

Nur ,Siti (2018). Pengaruh Penggunaan Media Pop Up Book Terhadap Keterampilan Menulis Deskripsi Siswa Kelas Iv Sdn Babatan 1 Surabaya . Jurnal JPGSD. Volume 06 Nomor 10 Tahun 2018, 1811-1821

Nurkholis (2013). Pendidikan Dalam Upaya Memajukan Teknologi . Jurnal Kependidikan, Vol. 1 No. 1 Nopember 2013

Pribadi, Benny A. 2009. Model Desain Sistem Pembelajaran. Jakarta: Dian Rakyat.

Safri Meilia. 2017. Pengembangan Media Belajar Pop-Up Book pada Materi Minyak Bumi. Jurnal Pendidikan Sains Indonesia, Vol. 05, No.01, hlm 107-113, 2017http://jurnal.unsyiah.ac.id/jpsi 
Satria, Tio Gusti. 2017. Meningkatkan Keterampilan Menyimak Melalui Pendekatan Saintifik Pada Anak Kelas Iv Jakarta Barat. Jurnal PGSD: Jurnal Ilmiah Pendidikan Guru Sekolah Dasar, 10 (2) 2017. Hal.114-120 PGSD FKIP Universitas Bengkulu

Sugiyono. 2017. Metode Penelitian Pendidikan (Pendekatan kuantitatif, kualitatif, dan R\&D). Bandung: Alfabeta.

Undang-Undang Republik Indonesia Nomor 20 tahun 2003. Sistem Pendidikan Nasional. 2012. Bandung: Citra Umbara. 